\title{
УДК 37.016:502]:376-056
}

\author{
Надія Голуб, \\ кандидат біологічних наук, \\ дочент кафедри спеціальної освіти \\ Уманського державного педагогічного \\ університету імені Павла Тичини \\ Володимир Голуб, \\ кандидат біологічних наук, \\ дочент кафедри теорії початкового навчання \\ Уманського державного педагогічного \\ університету імені Павла Тичини
}

\section{ФОРМУВАННЯ ПРИРОДНИЧИХ ПОНЯТЬ У ДІТЕЙ З МОВЛЕННСВИМИ ПОРУШЕННЯМИ ПРИ ВИВЧЕННІ ПРИРОДОЗНАВСТВА}

У статті розглядаються особливості формування природничих понять у дітей молодшого шкільного віку при мовленнєвих порушеннях. Належна увага приділяється етапам формування природничих понять при вивченні довкілля у початковій школі: мотивачійної та текстової підготовки до засвоєння природничих понять, організації чуттєвого сприймання ознак і властивостей предметів або явищ природи, організаиії розумової діяльності, узагальнення та вербалізачії суті поняття, введення сформованих понять у систему природничих знань. Аналізується використання основних засобів формування понять - емоџійно насичені завдання, дослідницька діяльність, плани-орієнтири, системні спостереження, народознавчий матеріал в умовах інклюзивного навчання.

Ключові слова: етапи, природничі поняття, мовленнєві порушення, інклюзивне навчання, корекиійна робота, діти молодшого шкільного віку, природне довкілля.

The article deals with the peculiarities of the formation of natural concepts within the children of the junior school age with speech disorders. Attention is paid to the stages of the formation of natural concepts in the process of studying the environment at primary school.

The stage of motivational and textual preparation for natural sciences acquisition has been revealed. The problem of the sustainable motivation of pupils at the lessons of natural science is studied. Positive emotional attitude for learning is ensured by the use in the educational process of interesting facts, vivid examples and information that meet the needs and interests of pupils.

Several steps of the motivational and textual preparation have been 
investigated. The stage of organizing sensory perception of signs is considered. It is mentioned that the features of objects or phenomena of nature are characterized by the the sensory experience of the child, without which it is impossible to assimilate knowledge - natural concepts.

Reasonable activity at the stage of mental activity organization has been analyzed. It aims at defining the essential features of the concept and begins with the presence in the minds of pupils of a sufficient number of concrete facts and representations. It is noted that the methods of mental activity such as analysis, synthesis, abstraction, comparison, generalization take place with speech impairment development.

The stage of generalization and verbalization of the essence of the concept continues with the conceptual generalizations can be ensured by repeating all the essential features and conducting vocabulary work.

The stage of introducing the prevailing concepts into the system of natural sciences provides a deep disclosure of a set of essential features of those objects and phenomena that embraces this concept. All concepts must be integrated into the system, revealing the relationships and intercourse between the elements of this system and placing them in a certain order and sequence.

The use of basic means of forming concepts - emotionally saturated tasks, research activities, plans, system observations, ethnographic materials, etc. Have been analyzed in the article.

Keywords: stages, natural concepts, speech disorders, inclusive education, correctional work, children of junior school age, natural environment.

У сучасних соціально-економічних умовах реформування освіти в Україні актуальним залишається питання пошуку шляхів удосконалення початкової освіти та підвищення якості підготовки молодших школярів 3 особливими освітніми потребами до життя в соціумі [12]. Важливе місце у такій підготовці відводиться освітній галузі «Природознавство», яке включає систему інтегрованих знань 3 різних природничих наук $\mathrm{i}$ на доступному рівні відображає цілісну науково-природничу картину світу [7].

Важливою умовою всебічного розвитку дітей молодшого шкільного віку є правильне формування мовлення. Рівень його розвитку визначає можливості молодших школярів у пізнанні природного довкілля, обумовлює характер відносин з однолітками та дорослими, характеризує психічний розвиток.

У початковій школі вперше формується система знань про природу, тому ставлення учнів до неї залежить від того, наскільки вони оволодівають цими знаннями, як у них буде сформовано екологічне мислення та культура. Виконанню різноманітних навчально-виховних 
завдань, формуванню позитивних рис особистості, вихованню відповідального ставлення до природи сприяє використання різноманітних методів проведення уроків природознавства.

Предмет «Природознавство» має значні можливості для формування знань про природне довкілля, оскільки грунтується на краєзнавчому принципі, тобто безпосередніх спостереженнях за явищами та об'єктами навколишнього середовища. Природничі знання тісно пов'язані з усіма видами людської діяльності, тому їх потрібно розглядати як одну 3 найважливіших складових частин спеціальної освіти, без якої неможливий повноцінний розвиток молодших школярів.

Одним із пріоритетних напрямів підвищення ефективності навчання природознавству $є$ формування природничих понять про живу природу у дітей молодшого шкільного віку. Разом з тим, для розкриття ролі людини у пізнанні світу природи доцільно посилити практичний характер змісту природознавства, а саме його гуманістичну спрямованість.

Дидактичні умови формування природничих понять розглядалися у працях Г. М. Аклієвої, О. А. Біди, О. М. Варакути, О. І. Мякушко та інших $[1 ; 3 ; 5 ; 11]$.

Теоретичні та методичні основи формування цілісних знань про живу природу стали предметом спеціальних досліджень К. Ж. Гузя, В. Ф. Моргуна, Р. М. Рославця, А. В. Степанюка та інших вчених [9; 10; $14 ; 15]$.

Питанням психолого-педагогічних основ інтеграції навчання на прикладі освітньої галузі «Природознавство» займалися М. Ф. Бабій, С. У. Гончаренко, К. Ж. Гузь, В. Ф. Моргун та Р. М. Рославець [2; 8; 9; $10 ; 14]$.

Актуальність означеної проблеми пояснюється новими вимогами до формування природничих понять в учнів початкових класів iз мовленнєвими порушеннями - послідовність процесу формування понять системою пізнавальних завдань, системний підхід у їх формуванні, використання знань, умінь і навичок, здобутих під час вивчення інших предметів тощо.

Аналіз досліджуваної проблеми у навчальному процесі загальноосвітньої школи 3 інклюзивними класами засвідчує наявність суперечностей між завданнями щодо формування у молодших школярів природничих понять, які передбачені у новітніх нормативних документах, та недостатнім рівнем їх вирішення. Діти молодшого шкільного віку досить часто засвоюють визначення поняття, не розуміючи його сутності, використовують терміни без усвідомлення наявних характерних ознак, відчувають труднощі у систематизації природничих понять. Для зняття цих суперечностей, на нашу думку, необхідно здійснювати спеціально організований процес формування понять та цілеспрямовану систему 
роботи в ньому, що дасть змогу поєднати процеси навчання і розвитку учнів.

Мета нашого дослідження - аналіз особливостей формування природничих понять у молодших школярів з мовленнєвими порушеннями під час вивчення предмета «Природознавство».

На сьогоднішній день не втрачають своєї актуальності методичні рекомендації К. П. Ягодовського щодо методики формування природничих понять у початковій школі [16]. Розроблена ним методика формування понять грунтується на єдності індуктивних та дедуктивних методів. Автор категорично виступав проти введення у програми і підручники термінів, які позначають незрозумілі для учнів поняття.

Окремі науковці, зокрема, О. А. Біда, О. М. Варакута О. І. Мякушко та інші стверджують, що найдоступнішими для дітей є конкретні поняття про об’єкти живої та неживої природи $[3 ; 5 ; 11 ; 13]$. Це пояснюється тим, що між конкретними поняттями $\mathrm{i}$ чуттєвим досвідом учнів, який зберігається у формі уявлень, існує безпосередній зв'язок.

Однією з умов досягнення цілісності знань про живу природу, їх розуміння та позитивної мотивації учнів до навчальної діяльності $\epsilon$ наступність. С. У. Гончаренко [8], К. Ж. Гузь [9], А. В. Степанюк [15] та інші розкривають наступність через поняття «інтеграція» і «система». Цілісність знань про живу природу передбачає сутнісну інтеграцію біологічних знань на основі наскрізних закономірних зв'язків, якими постають загальні закономірності природи. Необхідною умовою розуміння учнями цілісності живої природи є обгрунтування елементів знань на основі спільних, єдиних для усіх частин, що становлять цілісність, закономірностей природи $[8 ; 10]$. Основним чинником, який систематизує та об'єднує знання про живу природу, інтегрує їх, $\epsilon$ загальні закономірності, які існують у природі [8; 9]. Розуміння цілісності знань учнів про живу природу забезпечується на основі загального уявлення про природу як об'єкт вивчення природознавства.

P. М. Рославець та С. І. Орлов у процесі формування понять виділяють два етапи. На першому етапі засвоєння понять учні молодших класів перераховують відомі їм ознаки і властивості предметів, але не виділяють, які з них істотні, а які не істотні [14].

На другому етапі засвоєння понять молодші школярі навчаються виділяти характерні ознаки і властивості, узагальнюють їх, абстрагуючи до другорядних, неістотних ознак, і засвоюють певне поняття. Родові поняття молодші школярі конкретизують за допомогою відповідних видових понять (хижаки, рослиноїдні, всеїдні).

Визначення етапності формування природничих знань у спеціальній школі проводилося 3 урахуванням даних про рівні відображення об'єктів пізнання, представлених у працях О. М. Варакути [5] та 
Є. О. Неведомської [13]. Поетапне формування природничих знань $\epsilon$ одним із напрямів підвищення ефективності навчання природознавству учнів допоміжної школи. Цей процес вимагає спеціального підходу до підбору навчального матеріалу та до використання найефективніших методів і прийомів навчання природознавству.

Враховуючи особливості психічного розвитку дітей, Г. О. Блеч [4] виділяє п’ять етапів формування в учнів природничих знань:

- мотиваційна та текстова підготовка до засвоєння природничих понять;

- організація чуттєвого пізнання ознак, властивостей предметів або явищ, формування уявлень про них або актуалізація раніше сформованих уявлень;

- організація розумової діяльності, спрямованої на виділення істотних ознак;

- забезпечення узагальнення, вербалізація суті об'єкта, позначення його відповідним терміном;

- введення сформованого поняття в систему природничих понять.

Кожний етап формування природничих понять має свої особливості та завдання.

Завдання етапу мотиваційної та текстової підготовки до засвоєння природничих понять полягає у забезпеченні сталої мотивації учнів до уроків природознавства. Позитивне емоційне ставлення до навчання забезпечується використанням у навчальному процесі цікавих фактів, яскравих прикладів та інформації, які відповідають потребам й інтересам учнів. Все нове, яскраве, незвичне, цікаве, насичене живими образами, викликає емоційне переживання учнів. Зацікавити учнів, які мають мовленнєві порушення, можна змістом навчального матеріалу, але це вимагає систематичності в роботі вчителя, адже важливо не тільки викликати позитивні емоції, а й дбати, щоб вони не зникли.

Формування позитивних мотивів навчання можна забезпечити систематичним використанням додаткового пізнавального матеріалу, ігор, різноманітної наочності, змагань, незвичних способів постановки й оформлення навчального завдання, художньої літератури, засобів мистецтва тощо.

Формування природничих понять повинне постійно супроводжуватися мотивацією навчальної пізнавальної діяльності, вибір прийомів здійснення якої залежить від конкретних умов. Тому кожен етап формування природничих понять повинен цілеспрямовано включати різні прийоми мотивації. Найдоцільніше мотиваційну установку навчальної діяльності здійснювати на етапі актуалізації знань. Для цієї мети необхідно використовувати різні прийоми: розкривати пізнавальну мету і план уроку, показувати практичне значення теми [6;7]. 
Етап вивчення нового матеріалу повинен забезпечувати можливість включення у пізнавальну роботу якомога більше аналізаторів. 3 цією метою необхідно використовувати різноманітне наочне обладнання, порівнювати життєвий досвід для характеристики окремих подій і явищ у природі, широко застосовувати технічні засоби навчання та народознавчий матеріал [6].

На етапі узагальнення та систематизації знань доцільне використання загадок, кросвордів, ігор, введення елементів змагання між окремими групами учнів, тобто необхідно вводити елементи групової роботи $[1 ; 2 ; 7]$.

Етап організації чуттєвого сприймання ознак, властивостей предметів або явищ природи характеризується тим, що об'єкти, які сприймаються, становлять чуттєвий досвід дитини, без якого неможливе засвоєння знань - природничих понять. У зв'язку з цим обов'язковим елементом цього етапу формування природничих понять $\epsilon$ чуттєве сприймання - відображення реальних об'єктів, процесів i явищ навколишньої живої та неживої природи у свідомості. Свідоме сприймання може бути забезпечене лише попереднім підбором і демонструванням об'єктів природи, які своїм змістом відповідають поняттям, що формуються. Цілісність сприймання можна забезпечити використанням прийомів, які актуалізують чуттєвий досвід дітей - унаочнення, спонукання, коротке пояснення учителя. Підвищують навчальну активність учнів та сприяють формуванню й розвитку сприймання технічні засоби навчання, проведення дослідів, спостережень. Свідоме сприймання предметів i явищ навколишнього світу залежить від правильно організованих спостережень у природі та натуральних об'єктів, точного слова вчителя, вправ, які уточнюють сприймання та підвищення активності учнів [9].

Узагальненою, але разом із тим наочною формою чуттєвого відображення природи, сходинкою до вищої форми пізнання абстрактного мислення, яка виникає на основі відчуттів і сприймання, $є$ уявлення. «Замальовування предметів», яке змушує учнів уважно спостерігати за об’єктами, підмічати особливості їх форми, кольору тощо, $\epsilon$ одним із важливих прийомів формування природничих уявлень. Дефіцит часу на малювання предметів може зумовити використання карток або готових малюнків предметів, що вивчаються. Методичний прийом такої роботи полягає в тому, що на уроці учитель роздає учням малюнки або картки і просить наклеїти їх у робочий зошит, а під час закріплення чи повторення матеріалу на наступних уроках учні зможуть пригадати предмет і краще сформулювати свої відповіді.

Розумова діяльність на етапі організації розумової діяльності, спрямованої на виділення істотних ознак поняття, розпочинається за 
наявності у свідомості учнів достатньої кількості конкретних фактів, уявлень, тобто матеріалу для мислення, здобутого на попередньому етапі. В учнів, які мають вади мовленнєвого розвитку, реалізація усвідомлення сформованих уявлень та утворення нових може відбуватися лише за умови оволодіння прийомами розумової діяльності - аналізом, синтезом, абстрагуванням, порівнянням, узагальненням. Завдання учителя полягає у цілеспрямованій роботі над прищепленням таким учням умінь та навичок користуватися прийомами розумової діяльності, серед яких вирішальна роль належить порівнянню. Розв'язання цього завдання забезпечується через ряд вимог, реалізація яких на практиці дає можливість стимулювати дітей з вадами мовлення порівнювати об'єкти з метою пізнання їх сутності i на цій основі формувати у них початкові узагальнені уявлення. Такими вимогами є:

- вибір доцільної дидактичної ситуації, на якій застосування прийомів порівняння $\epsilon$ важливим чинником глибокого усвідомлення об'єкта природи, який вивчається;

- порівняння можна проводити між однорідними об'єктами, які мають подібні та відмінні ознаки;

- застосування інструкцій вчителя, детальних планів, схем, роздавального матеріалу, які використовуються як планиорієнтири для кращого орієнтування учнів під час самостійного порівняння;

- поступове збільшення кількості ознак, які порівнюються (проведення порівнянь за суттєвими ознаками);

- ускладнення процесу порівняння шляхом поступового переходу від порівнянь, які здійснюються на основі дій з предметами, до порівнянь об' єктів за уявленнями предметів.

Етап узагальнення та вербалізації суті поняття (словесного визначення, позначення відповідним терміном) продовжується поняттєвими узагальненнями, які викликають утворення окремих понять. Це можна забезпечити повторенням усіх істотних ознак (за запитаннями учителя чи схематичним планом) і проведенням словникової роботи.

Етап введення сформованих понять у систему природничих знань забезпечує глибоке розкриття сукупності суттєвих ознак тих предметів i явищ, які охоплює дане поняття. Всі засвоєні поняття необхідно об'єднати у систему, розкривши зв'язки та відносини між елементами цієї системи та розташувавши їх у певному порядку та послідовності.

Опиратися на набуті знання можна як під час сприймання та усвідомлення, так і під час закріплення та використання набутих нових знань. Нові ж знання можна засвоїти лише на основі вже набутих знань та умінь.

Нове завжди пізнається на основі порівнянь його з уже відомим 
учням, пошуком у ньому подібного і відмінного. Пізнання невідомого починається лише через відоме шляхом зіставлення, порівняння, узагальнення, абстрагування. Тому при поясненні нового матеріалу учитель повинен встановити взаємозв'язки з уже вивченим матеріалом, що забезпечує глибоке та свідоме засвоєння учнями нових знань. Крім того, використання вже знайомих учням знань під час засвоєння нових сприяє не лише кращому засвоєнню нових знань, а й запобігає забуванню засвоєного раніше. Якщо учні вільно оперують поняттями, вони вважаються сформованими.

У дослідженнях Р. М. Рославця наголошується, що вчитель під час бесіди з учнями повинен не просто заперечувати неправильну відповідь, а спрямовувати його думку на усвідомлення суперечностей між його твердженням та реальними фактами і тим спонукати шукати правильну відповідь на запитання [14]. Автор вказує, що формування елементарних понять починається від фактів узагальнення і продовжується індуктивним методом.

У результаті проведених нами досліджень встановлено, що учні 3 мовленнєвими порушеннями в умовах інклюзивних класів вивчають природознавство за типовою програмою, що викликає у них серйозні труднощі, пов'язані з розумінням та відтворенням навчального матеріалу.

Такі результати пов'язані з емпіричною спрямованістю навчальної програми та відповідною логічною структурою змісту навчального матеріалу у підручнику. Недостатня спрямованість навчальної програми на розкриття суттєвих зв'язків, зафіксованих в системі понять, є однією 3 причин низького рівня сформованості системи природничих знань у молодших школярів з мовленнєвими порушеннями.

На нашу думку, зміст навчальної програми та методи навчання повинні повніше враховувати специфіку пізнавальної діяльності молодших школярів 3 тяжкими мовленнєвими порушеннями та формувати в них цілісну картину світу. Це обумовлює необхідність розробки i впровадження у систему спеціальної освіти дітей із тяжкими порушеннями мовлення нових технологій навчання, які можуть покращити результативність засвоєння ними природничих понять i забезпечити корекційну спрямованість навчального процесу.

Особливості пізнавальної діяльності молодших школярів з тяжкими мовленнєвими порушеннями зумовлюють потребу у розробці системи корекційно-превентивних заходів для організації навчального процесу, оскільки специфіка їх психічної діяльності на сьогодні враховується недостатньо. 3 метою формування вираженого інтересу до матеріалів природничого характеру, бажання зрозуміти сутність явищ, які відбуваються у природі, визначення ї взаємозв'язку та взаємозумовленості у навчальний процес нами було запроваджено комплекс 
навчальних завдань для перевірки ефективності формування системи знань про живу природу у молодших школярів з мовленнєвими порушеннями.

У процесі дослідження ми звернули увагу на те, що учням подобаються емоційно насичені завдання. Вони викликали у молодших школярів підвищення інтересу до навчальної діяльності. 3 цією метою ми використовували завдання-загадки. Відповіді дітей завжди супроводжувалися демонстрацією слайдів. Для формування навичок зв'язного мовлення використовували описи різноманітних об'єктів.

При формуванні знань про природу використовували метод порівняння. Порівняння об'єктів проводили за планами-орієнтирами, які пропонували дітям під час проведення уроків. У подальшому порівняння проводили у процесі бесіди з елементами розповіді про живу природу, не використовуючи наочності.

Для закріплення вивчених понять ми працювали 3 роздавальними картками та колекціями. Для формування узагальнюючих понять використовували елементи українського фольклору - загадки, прислів'я, приказки, казки, легенди, прикмети, наприклад:

- Грім ранньою весною приносить холод.

- Грім у вересні - на теплу осінь.

- Грім у жовтні - зима малосніжна.

- Коли грім загримів, а лід не розтанув, буде холодне літо.

3 часом пропонували молодшим школярам пояснювати приказки i прислів’я, які дають змогу систематизувати та аналізувати вивчений матеріал. Наприклад:

- Чому листопад - онук вересня, син жовтня, а зимі - рідний брат?

- Вересень трусить груші у садках, а жовтень фарбує листя у лісах.

Для розвитку логічного мислення впроваджували у навчальний процес небилиці, завдяки яким діти, вкладаючи правильний сенс у переплутані різні явища, вчилися правильно використовувати різні поняття та явища природи. Такі завдання давали змогу активізувати розумову діяльність молодших школярів, виділити істотні ознаки об'єктів живої природи та узагальнити природничі поняття.

3 метою формування позитивних мотивів навчання ми систематично використовували додатковий пізнавальний матеріал та різноманітну наочність.

Під час розв’язування кросвордів ми пропонували відгадати загадки, відгадками яких були слова - вересень, жовтень, листопад, осінь. Запропоновані завдання давали змогу виділити істотні ознаки кожного календарного місяця та сформувати загальні поняття про пору року осінь.

Формування позитивних мотивів навчання забезпечували 
систематичним проведенням різноманітних ігор, які давали змогу забезпечити узагальнення понять і ввести їх у систему знань. Характерні ознаки рослин або тварин легко встановити під час таких ігор, як «Впізнай тварину», «Впізнай рослину за описом» тощо.

Провідне місце у системі формування природничих знань займають екскурсії у природу. Метою будь-якої екскурсії $\epsilon$ навчання учнів правильному баченню та усвідомленню об'єктів і явищ природи, вмінню встановлювати зв'язки i залежності між ними та розвиток у них спостережливості. На екскурсіях вчили молодших школярів спостерігати об'єкти живої природи в реальних умовах, оскільки спостереження є найважливішим джерелом знань про природу, яке розвиває уміння дивитися i бачити. Ми виходили 3 того, що спостереження $\epsilon$ безпосереднім, цілеспрямованим сприйняттям об'єктів живої природи різними органами чуття. Тому під час проведення екскурсій ми забезпечували розв'язання одного із важливих їх завдань - розвиток спостережливості школярів. Під час спостереження, при аналізі об'єктів ми спрямовували увагу молодших школярів на внутрішні, істотні ознаки, що допомагало їм отримати детальнішу інформацію про об'єкт, за яким проводилося спостереження.

Вивчаючи об'єкти живої природи, спостерігаючи процеси і явища у ній, ми вчили дітей порівнювати їх, намагатися робити найпростіші узагальнення, замислюватися над причинами явищ, що відбуваються. При цьому їхній розум вправляється в аналізі та синтезі одержаних відомостей, в умінні знаходити схоже та відмінне в предметах і явищах, в узагальненні схожих рис. Все це має велике значення для розвитку розумових здібностей, логічного мислення та мовлення учнів. У ході конкретних спостережень молодші школярі встановлювали зв'язки між різними природними об'єктами та явищами. Наприклад, спостерігаючи за температурою повітря, вони встановили складні зв'язки між живою i неживою природою: танення снігу, криги на водоймах, поява комах, розпускання бруньок, цвітіння вітрозапильних рослин. Всі ці зміни пов'язані 3 підвищенням температури повітря. Робота 3 розвитку елементарних уявлень на основі дослідження природних об'єктів значно збагачувала чуттєвий досвід молодших школярів, давала конкретний матеріал для розвитку та корекції їхнього мовлення і мислення. Вивчення об'єктів на уроці завершували спостереженнями за їх поведінкою у природних умовах (птахи, комахи), в умовах наближених до природи та в місцях їх розведення і утримання.

На нашу думку, такі поетапні завдання 3 поступовим ускладненням дають змогу ефективно формувати систему знань у дітей з мовленнєвими порушеннями. 
Одним із шляхів реалізації підвищення ефективності формування знань про живу природу $є$ включення у навчальний процес елементів дослідницької роботи над живими організмами та явищами природи. Уроки, які містили елементи дослідження, давали змогу структурувати зміст навчального матеріалу, який викликав зацікавлення в учнів та сприяв їхньому оптимальному розвитку. Характерна особливість таких уроків інформаційно-пізнавальна система навчання, тобто оволодіння готовими знаннями, пошук нових даних та розкриття внутрішньої сутності явищ через певні методичні прийоми.

Результати дослідження щодо застосування методики формування природничих понять у молодших школярів свідчать про те, що використання різноманітних інноваційних методів навчання підвищує пізнавальну активність дітей та сприяє ефективності формування природничих понять. Доведено, що ефективність процесу формування природничих понять у молодших школярів із мовленнєвими порушеннями забезпечується низкою дидактичних умов:

- здійсненням системно-структурного аналізу змісту навчального матеріалу;

- дотриманням етапності формування системи знань про живу природу;

- використанням міжпредметних зв'язків у формуванні природничих понять;

- підготовкою системи пізнавальних завдань для формування природничих понять.

Проведені дослідження дають змогу зробити наступні висновки.

Недостатній розвиток словесного узагальнення, обмежений термінологічний словник і порушення логічного мислення ускладнюють процес формування системи знань в учнів із мовленнєвими порушеннями, що проявляється у труднощах при визначенні ними понять, при описі та порівнянні об'єктів і явищ природи, узагальненні та систематизації навчальної інформації.

Використання різних засобів формування системи знань про природу на уроках предмета «Природознавство» має здійснюватися поетапно i систематично з поступовим введенням пізнавальних завдань у навчальний процес і базуватися на врахуванні мовленнєвих особливостей розвитку молодших школярів.

Проведене дослідження не вичерпує всіх аспектів проблеми формування природничих понять в молодших школярів із мовленнєвими

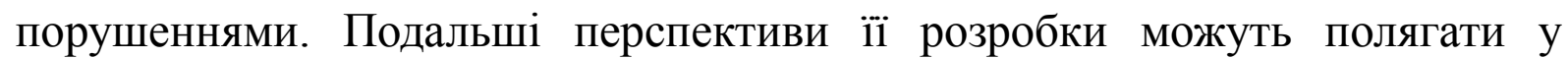
виявлені взаємозв'язку ефективності формування природничих понять 3 навчальною мотивацією учнів з особливими освітніми потребами. 


\section{СПИСОК ВИКОРИСТАНИХ ДЖЕРЕЛ}

1. Аквилева Г. Н. Натуральные средства обучения и методика работы с ними. Начальная школа. 2000. № 2. С. 31-37.

2. Бабій М.Ф. Нові психологічні напрями організації навчального процесу з природознавства. Луцьк: Редакційно-видавничий відділ «Вежа» Волинського держ. ун-ту ім. Л. Українки, 2003. 118 с.

3. Біда О. Формування природничих понять. Початкова школа. 2000. № 7. C. 23-25.

4. Блеч Г. О. Педагогічне забезпечення якості знань розумово відсталих учнів на уроках природознавства у допоміжній школі. Дефектологія. 2007. № 2. C. 46-52.

5. Варакута О. М. Дидактичні умови формування природничих понять в учнів початкових класів: дис. ... канд. пед. наук: спец. 13.00.09. Київ, 2000. 219 c.

6. Голуб Н. П. Психолого-педагогічні підходи до організації навчання дітей з вадами мовлення. Актуальні питання теорії та практики психолого-педагогічної підготовки майбутніх фахівиів: тези доповідей Всеукр. наук.-практ. конф. (Хмельницький, 20-21 квітня 2016 р.) / [ред. колегія: Є. М. Потапчук (голов. ред.), Т. Л. Левицька, Л. О. Подкоритова, В.К. Гаврилькевич, О.В.Варгата] / М-во освіти і науки України, Хмельницький нац. ун-т, каф. практ. психол. та педагог. [та ін.]. Хмельницький: ХНУ, 2016. С. 142-143.

7. Голуб Н. П. Спеціальна методика курсу «Я і Україна»: навч. посібник для студентів факультетів дошкільної та корекційної освіти вищих навчальних закладів / уклад. Надія Петрівна Голуб; Міністерство освіти України, Уманський ДПУ імені Павла Тичини. Умань: ВПЦ «Візаві», 2015. 115 с.

8. Гончаренко С. У. Інтеграція наукових знань і проблема змісту освіти. Постметодика. 1994. № 6. С. 2-3.

9. Гузь К.Ж. Теоретичні та методичні основи формування в учнів цілісності знань про природу. Полтава: Довкілля-К., 2004. 472 с.

10. Моргун В.Ф. Психолого-педагогічні основи інтеграції та диференціації навчання на прикладі шкільного циклу природничих дисциплін: курс лекцій. Полтава, 1996. 78 с.

11. Мякушко О. І. Цілісний підхід як основа формування природничих знань у дітей з порушеннями мовленнєвого розвитку. Дидактичні та соиіально-психологічні аспекти корекційної роботи у спеціальній школі. Київ: Ін-т дефектології АПНУ. 2000. Вип. 1. С. 137-142.

12. Національна доктрина розвитку освіти: збірник нормативних документів з освіти та виховання / упоряд. 3. М. Онишків. Тернопіль: Тернопільський національний університет імені Володимира Гнатюка, 
2006. $172 \mathrm{c}$.

13. Неведомська Є. О. Робота $з$ природничими термінами та поняттями: навч.-метод. посіб. Київ: Фенікс, 2006. 128 с.

14. Рославець Р. М., Орлов С. І. Природничі поняття в учнів початкових класів, їх формування та психологічні особливості. Науковий вісник Волинського національного університету імені Лесі Українки. 2012. Вип. 46. С. 66-69.

15. Степанюк А. В. Методологічні та теоретичні основи формування цілісності знань про живу природу: дис.. ... д-ра пед. наук: 13.00.01 / Тернопіль, 1999. 419 с.

16. Ягодовский К. П. Вопросы общей методики естествознания. Москва: Учпедгиз, 1951. $365 \mathrm{c.}$ 